\title{
E 207
}

\section{ヘリコバクターピロリ除菌治療の生活習慣病リスクファクターに及ぼす影響}

\author{
○堀田麻由美, 長坪由香, 蒲池文子, 原田早苗, 今井啓登, \\ 森口次郎, 宮㟝忠芳, 山田親久, 池田正之(京都工場保健会)
}

[目的] 近年 Helicobactor Pylori 菌 (H.P.) 陽性の再 発性消化性潰瘍に対する除菌治療の有効性が明 らかとなり、除菌治療が広く普及している。平成 12 年 11 月以降 H.P.に対する診断及び治療が保険適 応となったことにより、当施設でも多くの患者が除菌 治療を受け、効果を上げている。一方、除菌治療に 伴う逆流性食道炎や体重増加などの問題点も指摘 され始めている。

今回、除菌治療が生活習慣病リスクファクター指標 に及ぼす影響と自覚症状の変化、生活習慣の背景 を調査し、除菌後の生活指導の必要性について検 討した。

[対象] 対象は平成 12 年 11 月より平成 13 年 12 月 の間に当施設にて胃十二指腸内視鏡検査を受け、 消化性潰瘍·潰瘍瘢痕を指摘され、H.P.検査 (鏡検 法、培養法のいずれか)にて H.P.陽性と判断された 受診者 72 例(男性 62 例 女性 10 例)である。

[方法] 以下のような 2 群に分類して検討した。

(1)除菌群 57 例(男性 48 例 女性 9 例)

除菌治療を受け3〜6 ケ月後に内視鏡検査に

より H.P.陰性と判断された症例。

(2)非除菌群 15 例(男性 14 例 女性 1 例)

除菌治療を受けずに 6 ヶ月以上経過した症例。

いずれの群もH.P.陽性と判断された時期の值を観 察前値とし、除菌群では除菌治療 6 ヶ月後を、非除 菌群では 6 ヶ月経過した時期の值を観察後値とした。 各群で体重、BMI、収縮期・拡張期血圧、総コレステロー ル、中性脂肪(TG)、HDL-コレステロール(HDL-c)、LDL-コレ ステロール(LDL-c)、 $\gamma$-GTP、尿酸値(UA)、血糖(BS)、 $\mathrm{HbA1c}$ を測定し、喫煙、飲酒、運動などの生活習慣、 自覚症状の変化についてアンケートを実施した。
[結果] 除菌群、非除菌群では年齢に有意差を認 めなかった。(56.0 $11.4 、 53.1 \pm 1.9$ 歳) 除菌群では 前值と比べて体重及び BMI の有意な上昇が認めら れ、血液生化学検査でも HDL-c、r-GTP、UA の 上昇が認められた(表 $\mathrm{p}<0.05) 。 一$ 方、非除菌群 では観察期間中いずれの值にも有意な変化が認 められなかった。アンケート調査から、自覚症状の ある症例のみを対象とした場合、除菌群では非除 菌群に比較して有意に消化器症状の改善(胃痛、 胸焼けの減少、食欲増進)を認めた(図)。さらに 除菌群の中でも、除菌治療の前後で BMI が減少し た群では増加した群に比較して、1週間の総運動 時間 (通勤運動、積極的運動、立ち仕事) は多い傾 向がみられた。一方、喫煙習慣、飲酒習慣は BMI の変化に影響を及ぼさなかった。

[まとめ] 除菌治療後に体重は増加し、生活習慣 病リスクファクター指標の悪化が認められた。これ には日常の運動量及び自覚症状の改善による食 事摂取量の増加が関与していることが示唆された。 今後は除菌治療が生活習慣病に与える影響を考 慮し、除菌治療後の生活指導をしていく必要がある と考える。

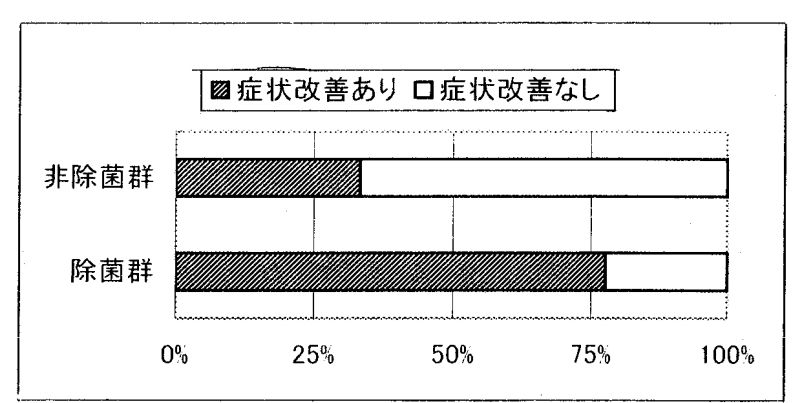

除菌群·非除菌群での各因子の変化

\begin{tabular}{|c|c|c|c|c|}
\hline & \multicolumn{2}{|c|}{ 除菌群 $(n=57)$} & \multicolumn{2}{|c|}{ 非除菌群 $(n=15)$} \\
\hline & 前 & 後 & 前 & 後 \\
\hline 体重 (kg) & $61.3 \pm 1.4$ & $62.3 \pm 1.5^{*}$ & $62.0 \pm 2.7$ & $62.7 \pm 2.5$ \\
\hline Body Mass Index $\left(\mathrm{kg} / \mathrm{m}^{2}\right)$ & $22.5 \pm 0.4$ & $22.8 \pm 0.4^{*}$ & $23.0 \pm 0.5$ & $23.3 \pm 0.5$ \\
\hline 総コレステロール $(\mathrm{mg} / \mathrm{dl})$ & $204.8 \pm 4.6$ & $206.4 \pm 4.3$ & $197 \pm 7.8$ & $201 \pm 5.6$ \\
\hline HDLコレステロール $(\mathrm{mg} / \mathrm{dl})$ & $53.3 \pm 1.8$ & $56.0 \pm 1.9^{*}$ & $53.7 \pm 3.0$ & $56.1 \pm 3.1$ \\
\hline 中性脂肪 (mg/dl) & $133.8 \pm 12$ & $141 \pm 12$ & $127 \pm 27$ & $96.7 \pm 8.3$ \\
\hline 尿酸 $(m \mathrm{~g} / \mathrm{dl})$ & $5.5 \pm 0.2$ & $5.7 \pm 0.2^{*}$ & $5.3 \pm 0.3$ & $5.7 \pm 0.4$ \\
\hline$\gamma-\mathrm{GTP}(\mathrm{IU} / \mathrm{I})$ & $22.7 \pm 3.2$ & $30.2 \pm 4.4^{*}$ & $24.9 \pm 5.8$ & $30.2 \pm 10.0$ \\
\hline 血 糖 $(\mathrm{mg} / \mathrm{dl})$ & $99.9 \pm 3.0$ & $99.2 \pm 3.0$ & $101.4 \pm 6.8$ & $97.6 \pm 7.2$ \\
\hline
\end{tabular}

